\title{
Immunocytochemical Studies on the Islet and the Gut of the Arctic Lamprey, Lampetra japonica
}

\author{
Ryogo YuI, Yukiji Nagata and Tsuneo FujITA \\ Department of Anatomy, Niigata University School of Medicine, Niigata, Japan \\ Received December 21, 1987
}

Summary. The endocrine cells and nerves in the islet and the gut of the arctic lamprey Lampetra japonica were examined immunocytochemically by using antisera against brain-gut peptides and amine.

The cellular composition of the islets as reported by previous researchers in European species of the lamprey was confirmed in the present study. The islet consisted exclusively of insulin immunoreactive cells in the larvae (ammocoetes), whereas in the adult somatostatin immunoreactive cells were added to the insulin immunoreactive cells; the gut epithelium in the adult was now devoid of somatostatin cells.

In the gut of the lamprey, the endocrine cells-which were flask-shaped with a cytoplasmic process extended to the lumen-were classified into three types in the larvae, but were represented by a single type in the adult. In the larval lamprey, the first type was immunoreactive for somatostatin, the second one for gastrin/cholecystokinin (CCK) and the third cell type was immunoreactive for glucagon, pancreatic polypeptide and FMRFamide, simultaneously. In the gut of the adult lamprey, the single type of endocrine cell reacted simultaneously to $\mathrm{C}$ terminal specific anti-glucagon serum, $\mathrm{N}$-terminal specific anti-glucagon serum, anti-bovine PP serum, anti-neuropeptide $Y$ serum and anti-FMRFamide serum. These cells occurred most frequently in the upper intestine, their distribution decreasing from the middle to the lower intestine.

Two types of peptide containing nerves were identified in the islet and the gut of the larval and adult lamprey. The first type of neurons (perikarya and fibers) was immunoreactive for serotonin and calcitonin generelated peptide (CGRP), and was located in the mucous and muscular layer of the intestine and in the islet. The second type of neurons contained both serotonin- and gastrin releasing peptide (GRP)-like immunoreactivities and was scattered exclusively in the muscular layer of the gut. In larval and adult lampreys, a few serotonin/ CGRP immunoreactive nerve cell bodies and beaded fibers were found in the connective tissue around the islet cell cords. These nerve fibers were sometimes closely ap- posed to the blood capillaries and to the islet cells. These findings indicate that a neuroendocrine correlation comparable with that in mammals may have been established in the islet of this most primitive vertebrate.

The islet and the gut endocrine systems of the cyclostomes have been assumed to represent the most primitive stage of differentiation in the evolution of the gastro-entero pancreatic (GEP) endocrine system of vertebrates. The digestive tract of the lamprey is devoid of a stomach, and the esophagus is connected directly to a straight intestine. No exocrine pancreas forms, rather, zymogen cells are distributed in the epithelium of the anterior intestine (BARRINGTON, 1972). In the larval lamprey, cell masses containing insulin and deserving the term "islets" occur in the submucosa of the anterior intestine near the opening of the bile duct. These islets are regarded as precursors of the pancreatic islets, which are associated with the exocrine tissue and first appear in vertebrates higher than chondrichthyes (FALKMER and ÖSTBERG, 1977; FUJITA et al., 1980). After the metamorphosis of the lamprey the islet cells proliferate into an islet larger in size and better vascularized; they form distinct cell cords (Titlbach and Kern, 1969; BARRINGTON, 1972; HARDISTY and BAKER, 1982).

A few immunohistochemical studies have been performed to localize bioactive peptides in the islets of the lampreys. In the larval lamprey Lampetra fuviatilis and $L$. planeri, the islets are composed of insulin immunoreactive cells (VAN NOORDEN et al., 1972; VAN NOORDEN and PEARSE, 1974). In the islet of the adult lamprey L. fluviatilis, somatostatin immunoreactive cells join the insulin producing ones (VAN NOORDEN et al., 1977; FALKMER and ÖSTBERG, 1977; FALKMER et al., 1978). 
The nervous supply of the islet tissue in cyclos tomes has been only cursorily investigated. EPPLE and BRINN (1975) reported that the islet tissue was essentialy devoid of nervous supply in Petromyzon marinus. As a more advanced animal, we examined the pancreas of the ratfish Chimaera monstrosa (Holocephalus) by immunocytochemical methods and demonstrated that peptide-containing nerves often terminated around the blood capillaries surrounding the pancreatic islets (YUI and FuJiTA, 1986). In further advanced animals up to mammals, the islet generally receives ample innervation. Therefore, a precise immunocytochemical investigation on the nervous elements in the islets of lamprey seemed necessary to elucidate the establishment of the neuroendocrine correlation in the pancreatic islet at the beginning of vertebrate evolution.

In the gut of the lamprey, only one type of endocrine cell has been described by VAN NOORDEN and PEARSE (1974). By using the immunofluorescence tech- nique, they reported that the cells reacting to anti-glucagon serum simultaneously reacted to anti-gastrin serum. The present study sought to examine this point more precisely and to explore other kinds of endocrine cells which might possibly occur in the gut epithelium of the lamprey, using antisera against peptides and amine (serotonin) which had not been used by the above authors.

The enteric nerve plexuses of the lamprey have been studied by Falck-Hillarp's fluorescence technique by BAUMGARTEN et al. (1973). In their observations on the gut of Lampetra fluviatilis serotonincontaining neurons were abundant, whereas dopamine- and noradrenaline-containing ones were scattered both in the submucous and myenteric plexuses. However, there has continued to be a need for immunocytochemical studies concerning the existence of peptides possibly contained in the nervous elements of the lamprey gut.
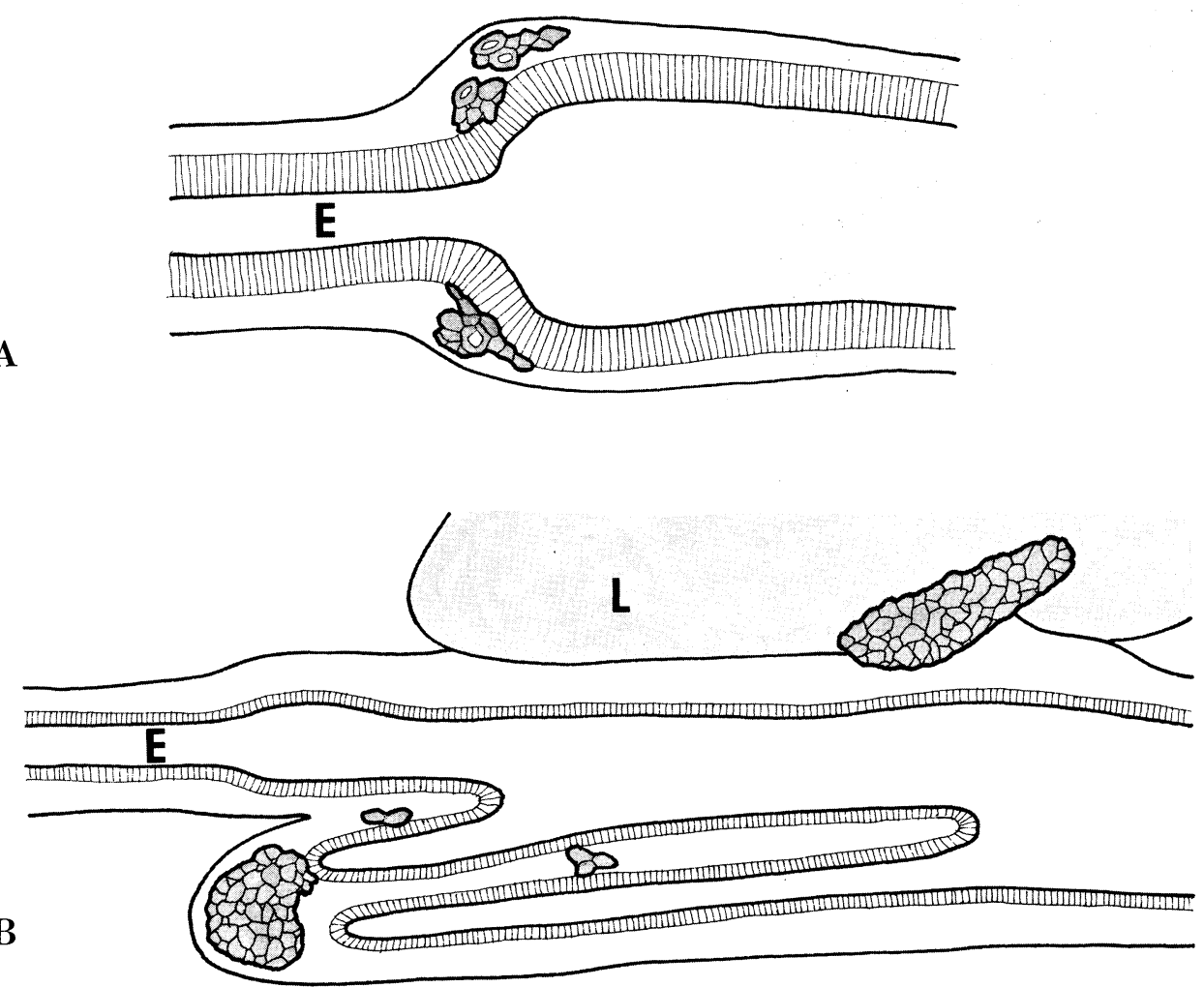

Fig. 1. Schematic representation of the gut and the islets (gray) in the larval (A) and adult lamprey (B). In the larva, an islet is located in the submucosa at the juncture between the esophagus and the intestine. In the adult, the islet is divided into cranial and caudal cords. $E$ esophagus, $L$ liver. 


\section{MATERIALS AND METHODS}

Both adult and larval lamprey Lampetra japonica were used in the present study. Adult specimens measuring $50-60 \mathrm{~cm}$ in body length were caught during anadromous migration at the mouth of the Agano River. Ammocoetes larvae ranging from 7 to $10 \mathrm{~cm}$ in body length were collected in a brook near the Shinano River from July to September. The gut and liver were removed and fixed in Bouin's fluid (without acetic acid) for 12 h. Tissue blocks were dehydrated in an ethanol series and, through xylen, embedded in paraffin. Serial sections of the islet and intestine were cut into sections $2-4 \mu \mathrm{m}$ in thickness.

Immunocytochemical examination was performed largely by the peroxidase-antiperoxidase (PAP) method (STERnBERGER, 1974). The deparaffin sections were hydrated and rinsed in phosphate buffered saline (PBS), to be incubated with normal swine serum (1: 40) for $30 \mathrm{~min}$. After rinsing in PBS, the sections were incubated with the primary antisera for $12 \mathrm{~h}$ at room temperature. They were rinsed in PBS and were treated with anti-rabbit IgG swine serum (1:40; DAKO) for $1 \mathrm{~h}$. The sections were rinsed in PBS and were successively treated with a PAP complex (1: 100 ; DAKO) for $1 \mathrm{~h}$. In instances of anti-insulin guinea pig serum being used as the primary antiserum, the indirect immunoperoxidase method (NAKANE and PIERCE, 1966) was performed. The sections were rinsed in PBS, then were treated with anti-guinea pig IgG goat serum conjugated with peroxidase (1: 80 ; Miles) for 1 h. The sections were rinsed in PBS and then were treated with $0.05 \mathrm{M}$ Tris-HCl buffer $\mathrm{pH} 7.6$, containing $3,3^{\prime}$-diaminobenzidine tetrahydrochloride $(0.1 \mathrm{mg} /$ $\mathrm{ml}$ ) and $0.03 \% \mathrm{H}_{2} \mathrm{O}_{2}$ for $10-15 \mathrm{~min}$.

The primary antisera used in the present study were as follows: anti-cholecystokinin 1-27 R5905 (1: 1000), anti-gastrin R1301 (1:2000), anti-gastrin releasing peptide R6902 (1 : 2000), anti-glicentin R4804 (1 : 2000), antiglucagon OAL-128 (C-terminal specific, $1: 2000$ ), antineurotensin R3502 (1:1000), anti-peptide HI 20-27 R8201 (1: 1000), anti-secretin R801 ( $1: 1000)$, anti-substance P R2402 (1:2000) and anti-vasoactive intestinal peptide R502 ( $1: 2000)$ provided by Dr. N. YANAIHARA, Shizuoka College of Pharmacy; anti-glucagon (Nterminal specific, $1: 3000)$, anti-insulin $(1: 800)$, antineurotensin $(1: 1000)$ and anti-somatostatin $(1: 4000)$ donated by Dr. S. ITo, Niigata University School of Medicine; anti-bovine pancreatic polypeptide (1: $8000)$ received from Dr. R. E. Chance (Eli Lilly Co.); anti-urotensin I supplied by Dr. T. ICHIKAWA, Tokyo Metropolitan Institute for Neurosciences; anti-calci- tonin gene related peptide (1:1800; Amersham); antiMet-enkephalin (1: 1000; UCB); anti-FMRFamide ( 1 : 1000 ; Immuno Nuclear Co.); anti-serotonin (monoclonal, 1: 200; Sera Lab.); anti-serotonin \#1234 (1: 4000) which was raised in rabbits by one of us (R. Y.).

As a preliminary study indicated that different kinds of antigens coexisted in identical nerves, the sections were examined by the double immunofluorescence technique. The sections were treated with rat monoclonal anti-serotonin antibody $(1: 200)$ for $4 \mathrm{~h}$, then rinsed in PBS. They were incubated with rhodaminelabelled goat anti-rat IgG (1:20; Cappel Laboratories) for $1 \mathrm{~h}$ followed by rinsing in PBS. The sections were further treated either with anti-GRP serum $(1: 100)$ or with anti-CGRP serum $(1: 100)$ for 4 $\mathrm{h}$; then after rinsing in PBS they were incubated with FITC-labelled swine anti-rabbit IgG (1: 40 ; DAKO). The double-immunostained sections were examined with a Leitz fluorescence microscope using filters L 2.1 and $\mathrm{N} 2.1$.

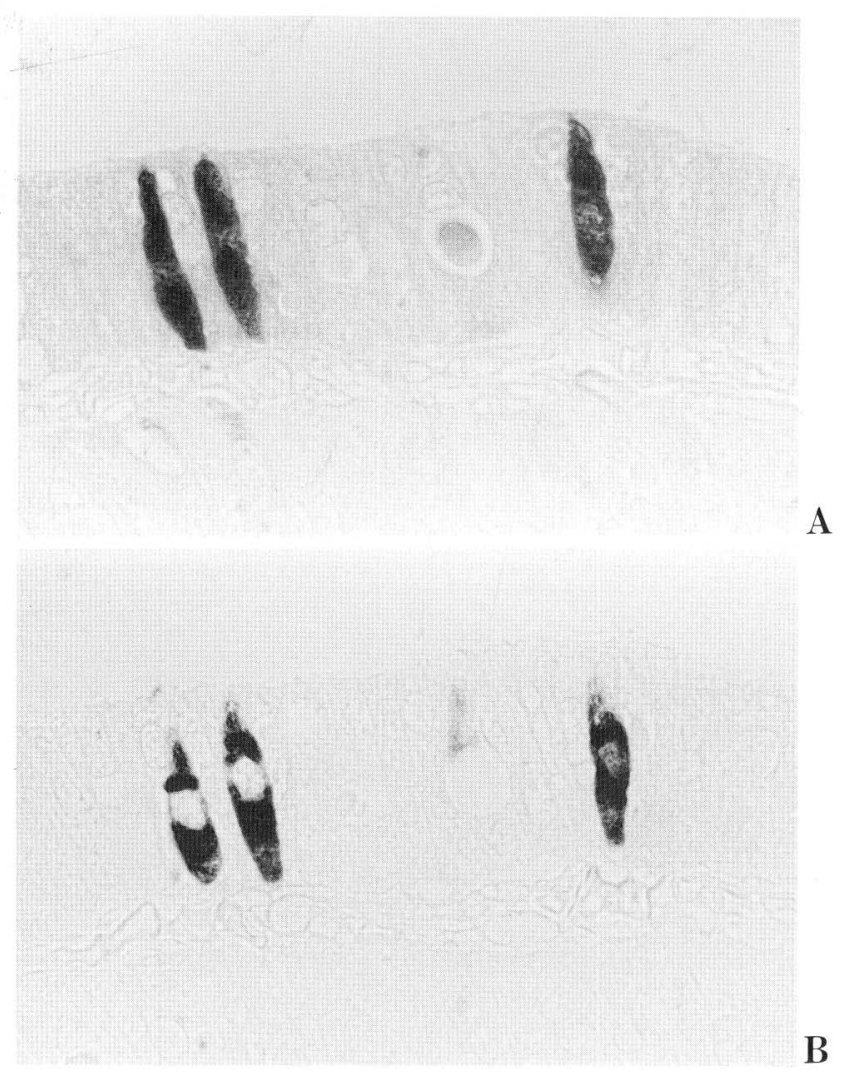

Fig. 2. Adjacent sections of the upper intestine of an adult lamprey reacting to anti-glucagon serum (A) and to anti-bovine PP serum (B). The identical endocrine cells contain both glucagon-like and PP-like immunoreactivities. $\times 700$ 
The specificity of the immunostaining was checked by the use of a normal rabbit or guinea pig serum in place of the primary antiserum, and by the use of the primary antiserum inactivated with the relevant antigen (10-20 $\mu \mathrm{g}$ peptide/ml diluted antiserum).

\section{RESULTS}

\section{Endocrine Cells in the Islet and the Gut}

In the larval lamprey, the islet tissue was located in the submucosa at the uppermost portion of the gut (Fig. 1). The islet was composed of insulin immunoreactive cells which were polygonal or pyramidal in shape and were arranged to form follicles. The follicles proliferated and enlarged with the growth of the larvae. In the large larvae $5-7 \mathrm{~cm}$ in body length, the islet consisted of complexes of follicles measuring $70-100 \mu \mathrm{m}$ in diameter. The follicles were encapsulated by the connective tissue. Blood capillaries were located in the connective tissue around the follicles.

In the gut epithelium of the larval lamprey, three types of endocrine cells were localized. The first type was immunoreactive for somatostatin, the second one for gastrin/cholecystokinin (CCK) and the third and most numerous cell type was immunoreactive for glucagon, pancreatic polypeptide(PP) and FMRFamide, simultaneously. These three types of cells were basalgranulated and open types which extended a process to the lumen. These cells were especially abundant in the upper part of the intestine in close vicinity to the opening of the bile duct and to the islets.

In the adult lamprey, the composition and the arrangement of the GEP endocrine system were changed from the larval status. The islet tissue was distributed in two discrete groups, namely cranial and caudal cords (Fig. 1). The cranial cords were aggregated in the submucosa at the juncture between the esophagus and the intestine. The caudal cords fit into an indentation in the liver and were surrounded by a connective tissue which continued to the capsule of the liver. These cords were spherical or polygonal in shape; the cords as a whole were usually demarcated with a thin connective tissue. Blood capillaries ran in the connective tissue intervening the cellular cords (Fig. 8). Half of the islet cells were immunostained with anti-insulin serum, while the rest were reactive to anti-somatostatin serum (Fig. 8).

In the intestine of the adult lamprey, a large number of open type basal-granulated cells which contained glucagon-, PP- and FMRFamide-like immunoreactivities

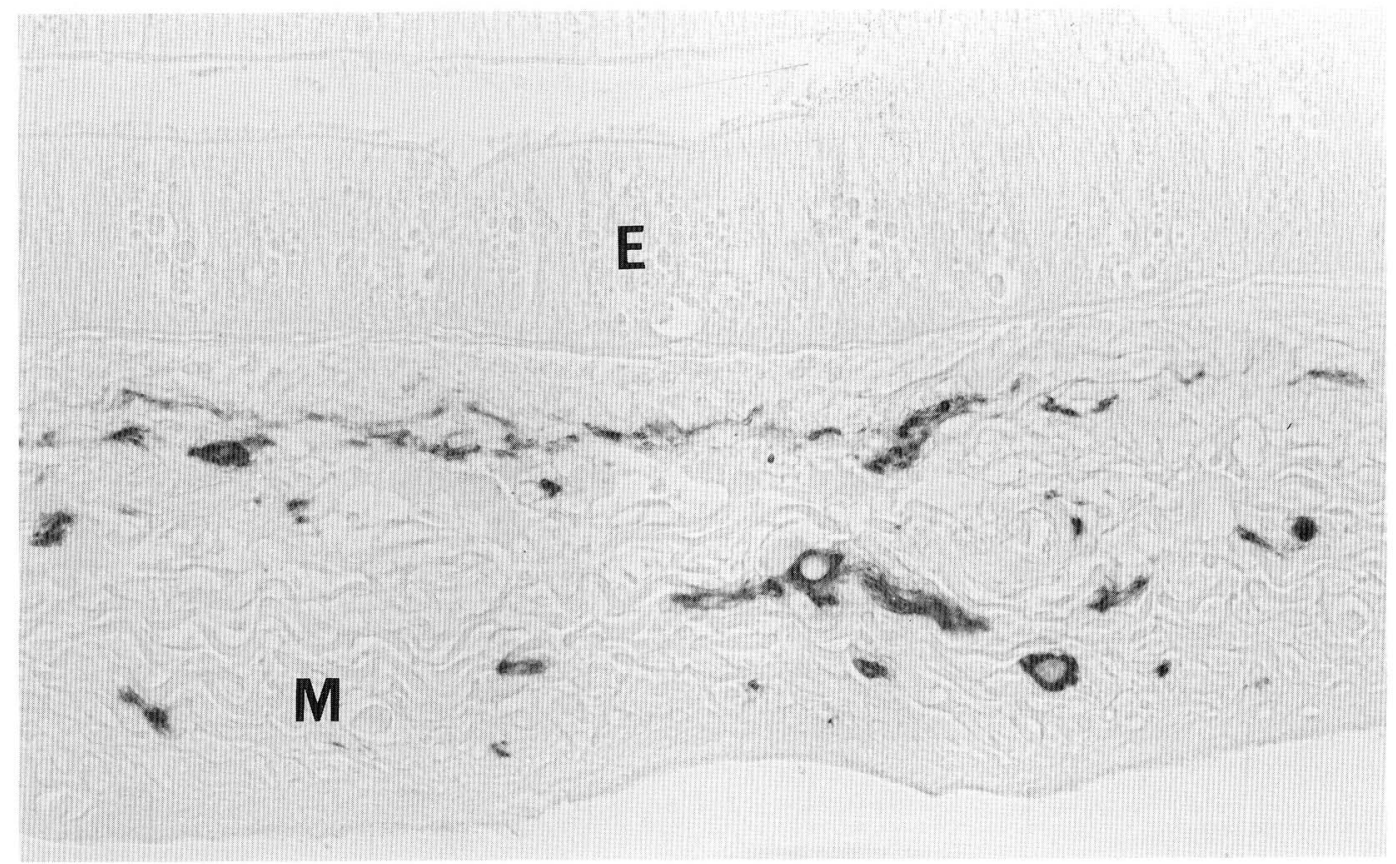

Fig. 3. CGRP immunoreactive nerves distributed in the lower intestine of an adult lamprey. Beaded nerve fibers and neuronal somata containing CGRP-like immunoreactivities are abundant in the submucosal layer. They are meager in the muscular layer $(M)$. $E$ epithelium. $\times 360$ 
were observed frequently in the upper intestine but sporadically in the middle and lower intestines. Serial consecutive sections of the gut were immunostained with anti-glucagon serum, anti-PP serum and antiFMRFamide serum, respectively. It was proved that three kinds of peptides were contained in the identical basal-granulated cells. Figure 2 shows that glucagon- like and PP-like immunoreactivities were localized in the same endocrine cells. Somatostatin immunoreactive cells which occurred abundantly in the gut epithelium of the larvae were no longer found in the gut of the adult specimens. No other endocrine cells binding to antisera against mammalian gut peptides were detected throughout the intestine.
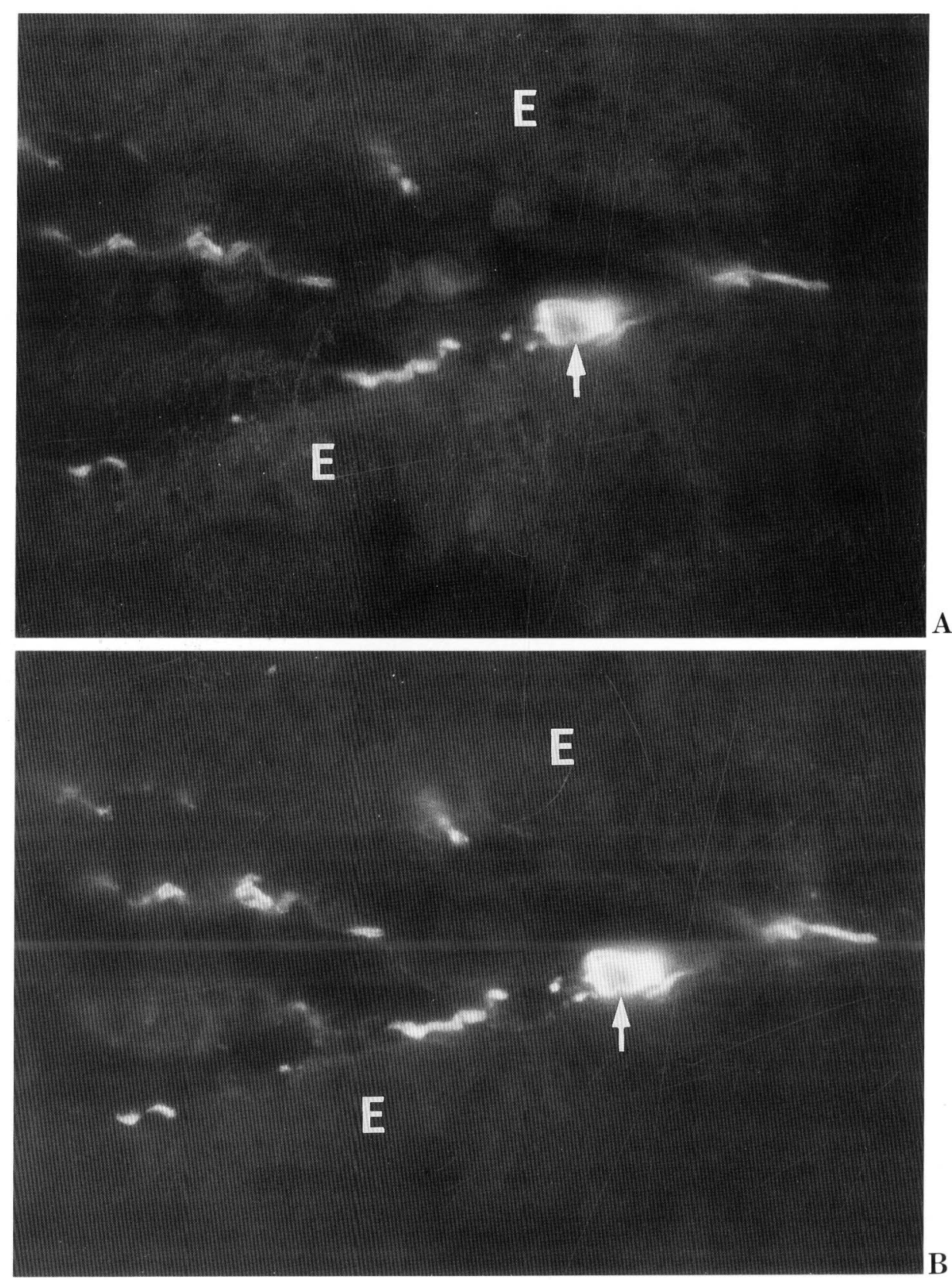

Fig. 4. Immunofluorescence micrograph of the islet of an adult lamprey. The section is immunostained by anti-serotonin serum (A), followed by anti-CGRP serum (B). The identical neuronal somata (arrows) and beaded nerve fibers contain both serotonin-like and CGRP-like immunoreactivities. $E$ epithelium. $\times 1,700$ 


\section{Nerves in the Gut and Islet}

In the gut of the larval lamprey, nerve fibers and neuronal somata which contained CGRP-, serotonin- and GRP-like immunoreactivities were scattered in the mucous and the muscular layer. The islet of the ammocoetes larva revealed a few nerve fibers immunoreactive to anti-CGRP serum and anti-serotonin serum to be localized in the connective tissue around the islet follicles.

In the adult lamprey, increased numbers of immunoreactive nerves were localized in the lamina pro- pria mucosae and the muscular layer of the intestine and scattered in the islet. CGRP immunoreactive nerve cell bodies and fibers were found both in the intestine and in the islet (Fig. 3). Some sections of the gut, treated with the double immunofluorescence technique, proved that serotonin- and CGRP-like immunoreactivities were contained in identical nerve cell bodies and fibers (Fig. 4). The GRP immunoreactive nerve cell bodies and fibers were shown to contain serotonin-like immunoreactivity by using the same double immunofluorescence technique.

The nerve cell bodies and fibers containing sero-

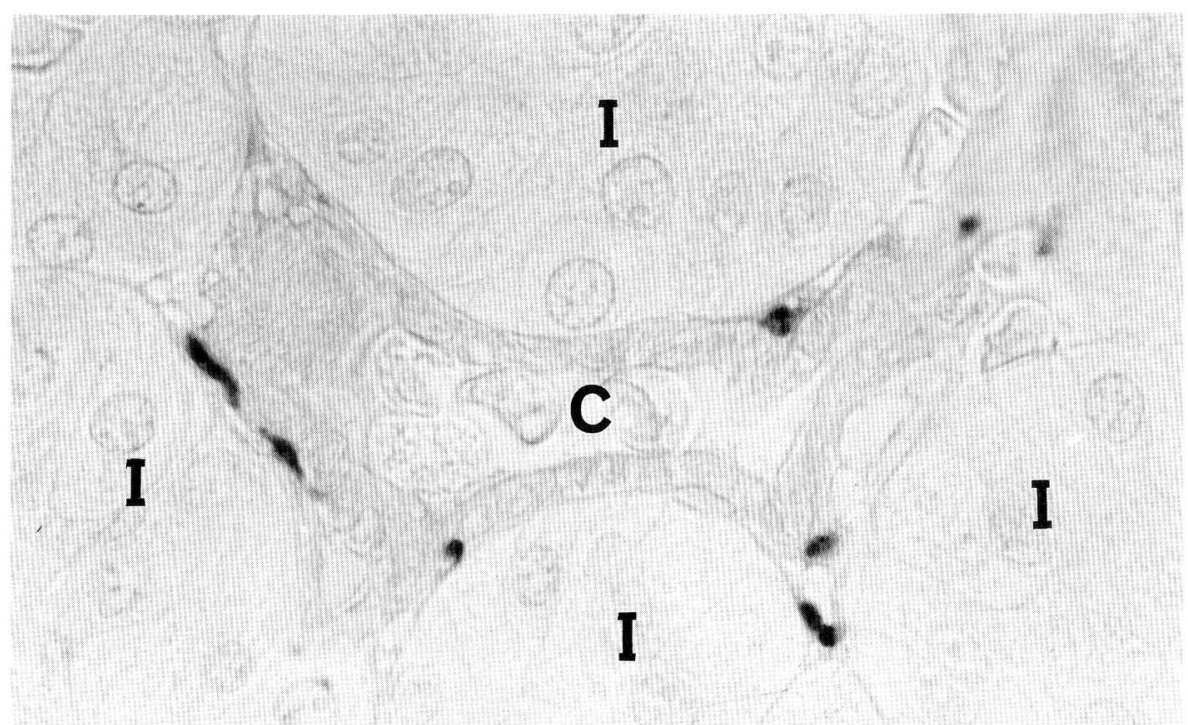

A

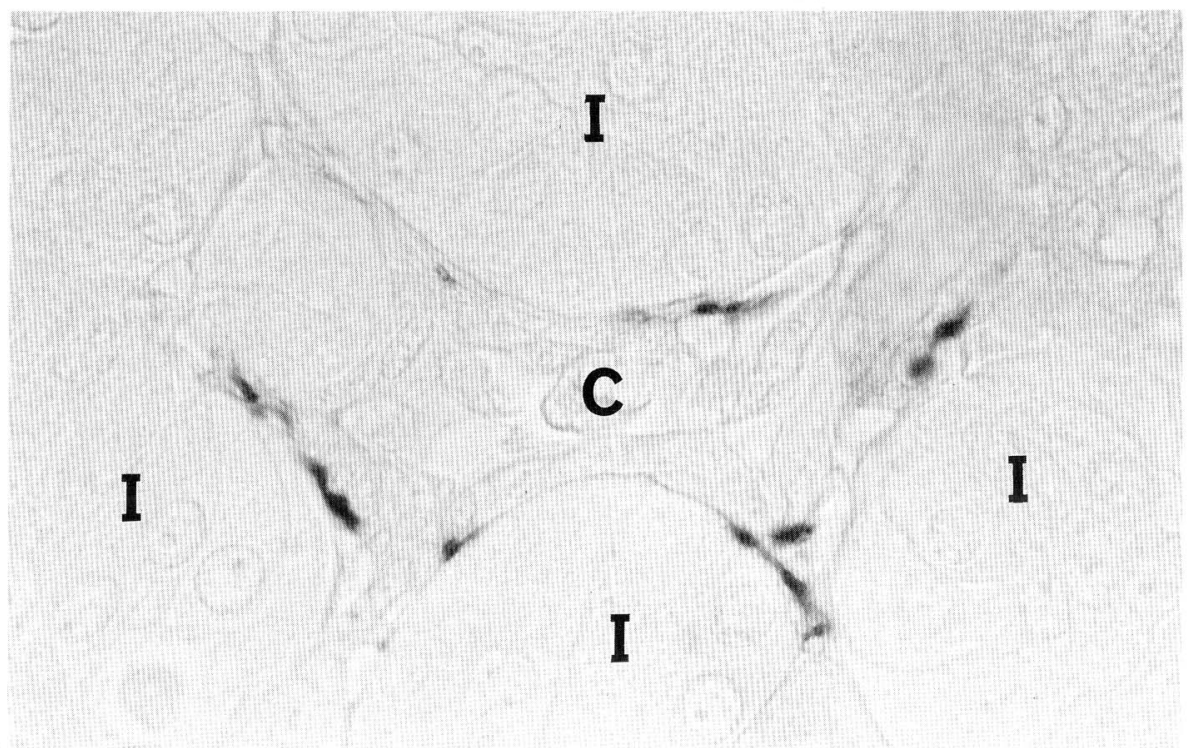

B

Fig. 5. Adjacent sections of the islet of an adult lamprey immunostained with anti-serotonin serum $(\mathbf{A})$ and with anti-CGRP serum (B). $C$ blood capillary, $I$ islet cell cord. $\times 1,000$ 
tonin-and CGRP-like immunoreactivities predominated over GRP/serotonin immunoreactive ones. A thin bundle of serotonin/CGRP immunoreactive nerve fibers which were mostly beaded in structure was found in the connective tissue of the submucosa, the beaded fibers usually running in a rostro-caudal direction
(Fig. 3). Serotonin/CGRP immunoreactive neuronal somata occurred singly or gathered in small groups. They measured 10-15 $\mu \mathrm{m}$ in diameter and issued processes bipolarly; their varicose nerve fibers sometimes made terminals on those other neuronal somata which were not immunostained with any of
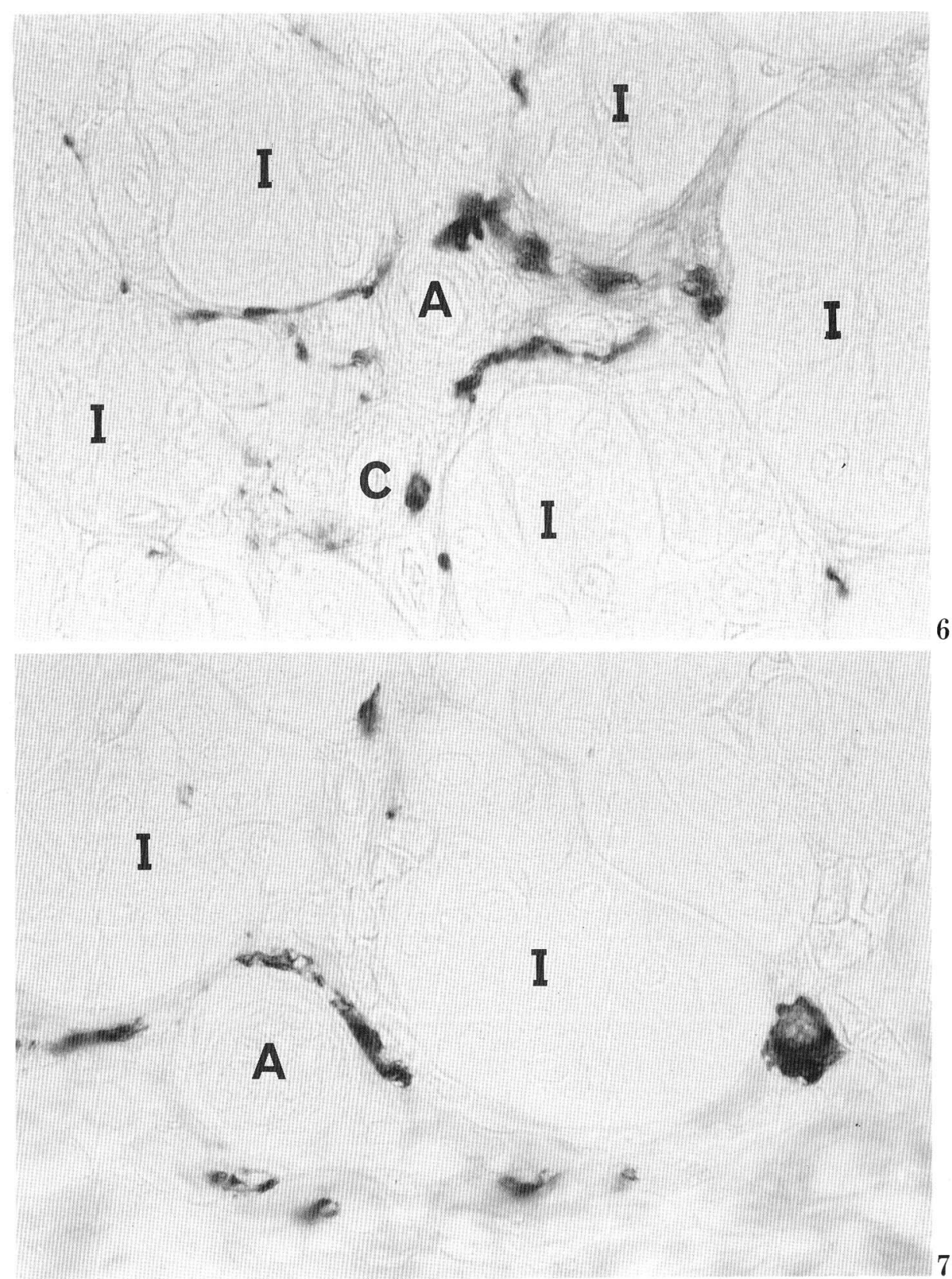

Fig. 6. Beaded fibers immunoreactive for CGRP in the connective tissue between islet cell cords $(I)$. Varicose terminals are sometimes located close to a blood capillary $(C)$ and approach islet cell cords. $A$ arteriol. $\times 800$

Fig. 7. A neuronal somata binding to anti-CGRP serum in connective tissue close to islet cell cords. Beaded nerve fibers run in the connective tissue. $A$ arteriol, $I$ islet cell cord. $\times 800$ 

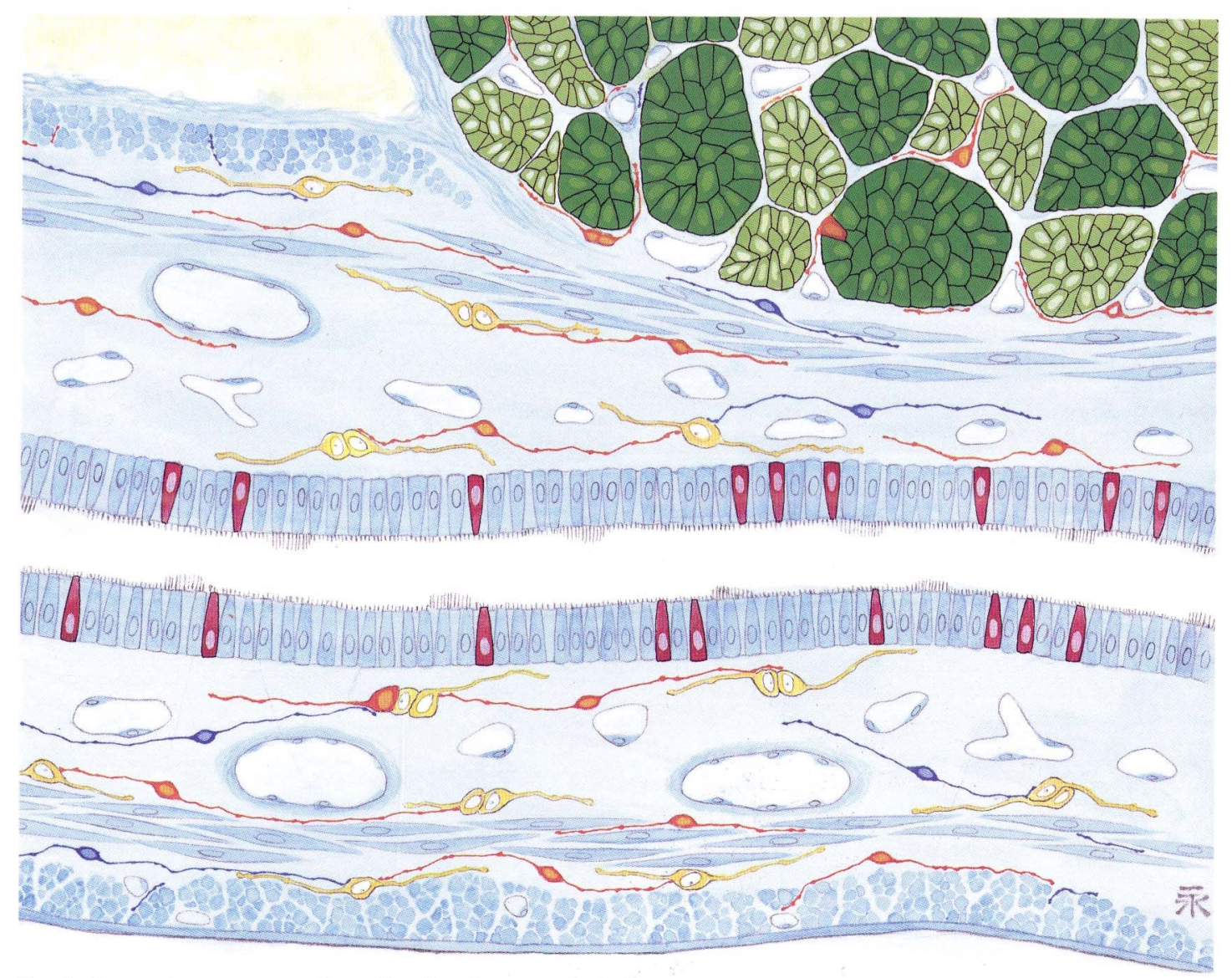

Fig. 8. Schematic representation of endocrine cells and neurons in the upper intestine and caudal cords of islet of an adult lamprey. The islet consists of somatostatin cells (dark green) and insulin cells (light green). In the gut epithelium, open-type endocrine cells (red) are immunoreactive for glucagon, PP and FMRFamide. Neuronal somata and beaded fibers containing serotonin- and CGRP-like immunoreactivities (orange) are distributed in the submucosa and the muscular layer of the intestine and in the islet. Serotonin/GRP immunoreactive neurons (blue) are scattered in the submucosa and the muscular layer of the intestine. Nonimmunoreactive neurons appear in yellow.

the antisera applied.

Beaded nerve fibers containing GRP-like immunoreactivities were located sporadically in the submucous tissue and the muscle layer. GRP immunoreactive nerve cell bodies which were classified as a bipolar type were observed in the myenteric plexus (Fig. 8). Neuronal somata and fibers which remained unstained by any antisera accounted for about a half of the total population of nerves found in the intestine (marked in yellow in Fig. 8).

A small number of nerve cell bodies and fibers which immunoreacted simultaneously for serotonin and for CGRP were scattered in the islet of the adult lamprey. Serial consecutive sections were treated with anti-serotonin serum and with anti-CGRP serum, alternately, and it was shown that the identical nerves contained both serotonin- and CGRP-like immunoreactivities (Fig. 5). The nerve fibers found in the islet were originated either from the neuronal somata in the islet or from those in the intestine (Figs. 6, 8). The nerve cell bodies in the islet were polygonal in shape, measuring $10 \mu \mathrm{m}$ in diameter, and issued beaded fibers (Figs. 7, 8). They usually formed varicose terminals in the perivascular space of the blood vessels or in the connective tissue between the islet cell cords. A detailed observation of the nerve terminals proved that they were located among collagen bundles and lay at some distance from the islet cells or from capillaries. 


\section{DISCUSSION}

In the intestinal epithelium of the lamprey, VAN NOORDEN and PEARSE (1974) have shown that basalgranulated cells stained with the argyrophil method and with lead hematoxylin are numerously distributed along the whole length of the gut. They reported that all the argyrophil cells were simultaneously immunoreactive for glucagon and gastrin (VAN NOOR. DEN and PEARSE, 1974). In the present study, a large number of glucagon immunoreactive cells were found in the gut epithelium but did not bind to anti-gastrin serum. The reason for this discrepancy does not seem to be lie in differences with the antisera used. In the adult lamprey, no cells immunoreactive for gastrin or CCK were found in the intestine. On the other hand, ammocoetes larvae revealed gastrin- and CCK-like immunoreactivities in some basal-granulated cells which were clearly different from the glucagon immunoreactive cells.

The glucagon immunoreactive cells bound both to anti-C-terminal glucagon serum and to anti- $\mathrm{N}$ terminal glucagon serum. In the intestine of mammals, it has been established that C-terminal anti-glucagon serum does not react to the intestinal glucagon cells, whereas $\mathrm{N}$-terminal glucagon antiserum binds to both intestinal and pancreatic glucagon cells (LARSSON et al., 1975 ; RAVAzzola et al., 1979). The present study showed that in the gut of lamprey the identical cells reacted to four kinds of antisera, namely anti-glucagon, anti-bovine PP, anti-neuropeptide Y (NPY) and anti-FMRFamide serum. FALKMER et al. (1981) have referred briefly to the occurrence of PP cells in the intestine of the hagfish and the lamprey. Recently, a peptide YY (PYY) has been isolated and the major part of its amino acid sequence proved to be similar to PP (TATEMOTo et al., 1982). The PYY immunoreactive cells have been shown to be localized in the distal intestine of several mamalian species, those identical with cells immunoreactive for glicentin, i.e., guttype glucagon (BöTTCHER et al., 1984, 1986). From this coexistence in the endocrine cells of the mammalian gut peptides, it is reasonable to deduce that the gut glucagon/PP cells in the lamprey may be homologous to the PYY cells in mammals.

Extracts of lamprey gut have demonstrated a capability to exert secretin-like and pancreozymin-like actions upon the pancreas of the rat (BARRINGTON and DockRAY, 1970; DoCKRAY, 1977). Furthermore, extracts of lamprey intestine have cross-reacted to antisera specific for the carboxyl terminus of mammalian gastrin and CCK (DOCKRAY, 1977). In the present study, a small number of endocrine cells were found immunoreactive to both anti-gastrin serum and anti-CCK serum.

In the present study, three types of endocrine cells were distinguished in the gut of the larvae, though only one of them was identified in that of the adult lamprey. In the hagfish Myxine glutinosa, REINECKE et al. (1980) observed neurotensin immunoreactive cells in the upper intestine. This type of cell, however, could not be detected in the present study. On the other hand, more primitive deuterostomes have been shown in immunohistochemical studies to possess numerous kinds of gut endocrine cells which contain different bioactive peptides. The digestive tract of the cephalochordate Branchiostoma lanceolatum contained eight types of peptide hormone immunoreactive cells (VAN NOORDEN and PEARSE, 1976; REINECKE 1981). In ascidian Ciona intestinalis and Styela clava, nine kinds of peptide containing cells were localized in the esophagus, stomach and intestine (FRITSCH et al., 1978, 1982; BEVIS and ThORNDYKe, 1978, 1979). The scantiness of the endocrine cell types found in the gut of the adult lamprey was contrary to our expectation. This may be explained in that the animals used in the study were spawning and the digestive system of those fish was rather degenerative. The endocrine cells in the lamprey gut might reduce to a single type at this state. The present study revealed that the endocrine cells in the intestine of the adult lamprey contained at least three kinds of immunoreactivities in the single cell type. This indicates that the cells secrete a set of peptides, presumably being involved in a manifold endocrine regulation.

A prominent change was found in the distribution of somatostatin cells after metamorphosis. In the larvae, somatostatin immunoreactive cells were located in the intestine; however, in the adult they disappeared from the intestinal epithelium and constituted about a half of the islet cells in the adult lamprey. This finding confirms previous immunohistochemical observations in the lamprey Petromyzon marinus (VAN NOORDEN et al., 1977; ElliotT and Youson, 1986, 1987). In most vertebrates higher than chondrichthyes, somatostatin cells are shared by the pancreatic islets and the gut (FALKMER et al., 1977). Therefore, the change in location of somatostatin cells after metamorphosis in the lamprey seems to be unique, as such a dramatic change is not known in any other vertebrates.

The islet cells of the adult lamprey have been classified into four types on the basis of histochemical staining and the ultrastructural features of the secretory granules (BRINN and EPPLE, 1976). The present study could not distinguish subtypes either for insulin 
cells or for somatostatin cells of the islets.

In the islets of larval and adult lamprey, a small number of serotonin and CGRP immunoreactive nerve cell bodies and varicose fibers were demonstrated. The nerve terminals were situated close to the islet cells and were occasionally found in the pericapillary space among the islet cell cords. It has been found in some mammalian and reptilian pancreatic islets that nerve fibers terminate in the pericapillary space and that neuronal secretions may be released into the blood stream, which, after flowing through the islet, drain to the exocrine pancreas via the insuloacinar portal system. This type of nerve terminal was designated the "neurosecretory" or "hemocrine" type (Fujita and Kobayashi, 1979; Fujita et al., 1981). Recent immunocytochemical studies in the pancreatic islets of the ratfish Chimaera monstrosa have revealed that peptide-containing nerve fibers terminate in the pericapillary space. In the islets of the lamprey, the location of the nerve terminals indicates the possibility that they may release CGRP and serotonin in the connective tissue (paracrinia), thus directly affecting the islet cells. They may also release the substances into the blood capillaries, thus reaching the islet cells by microcirculation (microhemocrinia). It is therefore assumed that the nerve terminals in the islet may be involved in regulating the functions of islet cells in this most primitive vertebrate.

The present study revealed the existence of two types of nerves, namely serotonin/CGRP and serotonin/GRP immunoreactive neuronal somata and fibers in the gut. BAUMGARTEN et al. (1973) have described the occurrence of serotonin-, dopamine- and noradrenalinecontaining neurons in the gut of Lampetra fluviatilis. In their observation, serotonin-containing neurons were distributed all along the gut whereas dopamine- and noradrenaline-containing neurons were scattered in the foregut and midgut. The distribution of serotonin neurons in the present observations confirms the report by BAUMGARTEN et al. (1973). As for the dopamine and noradrenaline immunoreactive nerves, we did not use antibodies relevant for their detection in the present study. The ultrastructural observation by BAUMGARTEN et al. (1973) that nerve somata and processes contain both small granular vesicles and many large granular vesicles (75-160 nm in size) seems compatible with our immunohistochemical finding indicating the occurrence of bioactive peptides in the neurons in question.

Acknowledgements. The authors express cordial gratitude to Prof. N. YANAIHARA of the Shizuoka College of Pharmacy, Dr. S. ITo of the Niigata University School of
Medicine, Dr. R. E. Chance of Eli Lilly and Co. and Dr. T. ICHIKAWA of the Tokyo Metropolitan Institute for Neurosciences for providing the valuable antisera and antigens.

\section{REFERENCES}

Barrington, E. J. W.: The pancreas and intestine. In: (ed. by) M. W. Hardisty and I. C. PotTer: The biology of lampreys, vol. 2. Academic Press, London and New York, 1972 (p. 135-169).

Barrington, E. J. W. and G. J. Dockray: The effect of intestinal extracts of lampreys (Lampetra fluviatilis and Petromyzon marinus) on pancreatic secretion in the rat. Gen. Comp. Endocrinol. 14: 170-177 (1970).

Baumgarten, H. G., A. BJörklund, L. LaChenmayer, A. Nobin and E. Rosengren: Evidence for the existence of serotonin-, dopamine-, and noradrenaline-containing neurons in the gut of Lampetra fluviatilis. $Z$. Zellforsch. 141: 33-54 (1973).

Bevis, P. J. R. and M. C. Thorndyke: Endocrine cells in the oesophagus of the ascidian Styela clava, a cytochemical and immunofluorescence study. Cell Tiss. Res. 187: 153-158 (1978).

- : A cytochemical and immunofluorescence study of endocrine cells in the gut of the ascidian Styela clava. Cell Tiss. Res. 199: 139-144 (1979).

BötTcher, G., K. SJölund, E. Ekblad, R. Håkanson, T. W. SchWARTZ and F. SundLeR: Coexistence of peptide YY and glicentin immunoreactivity in endocrine cells of the gut. Regul. Peptides 8: 261-266 (1984).

Böttcher, G., J. Alumets, R. Håkanson and F. Sund LER: Co-existence of glicentin and peptide YY in colorectal L-cells in cat and man. An electron microscopic study. Regul. Peptides 13: 283-291 (1986).

Brinn, J. E. and A. EPPle: New types of islet cells in a cyclostome, Petromyzon marinus L. Cell Tiss. Res. 171: 317-329 (1976).

DockRAY, G. J.: Molecular evolution of gut hormones: Application of comparative studies on the regulation of digestion. Gastroenterology 72: 344-358 (1977).

ElliotT, W. M. and J. H. Youson: Immunocytochemical localization of insulin and somatostatin in the endocrine pancreas of the sea lamprey, Petromyzon marinus L., at various stages of its life cycle. Cell Tiss. Res. 243: 629-634 (1986).

- : Immunohistochemical observations of the endocrine pancreas during metamorphosis of the sea lamprey, Petromyzon marinus L. Cell Tiss. Res. 247: 351-357 (1987).

EPple, A. and J. E. Brinn, Jr.: Islet histophysiology: Evolutionary correlations. Gen. Comp. Endocrinol. 27: 320-349 (1975).

Falkmer, S. and Y. Östberg: Comparative morphology of pancreatic islets in animals. In: (ed. by) B. W. VoLK and K. F. Wellmann: The diabetic pancreas. Plenum Press, New York and London, 1977 (p. 15-59).

Falkmer, S., R. P. Elde, C. Hellerström, B. Peters son, S. Efendić, J. Fohlman and J.-B. Siljevall: 
Some phylogenetical aspects on the occurrence of somatostatin in the gastro-entero-pancreatic endocrine system. A histological and immunocytochemical study, combined with quantitative radioimmunological assays of tissue extracts. Arch. Histol. Jap. 40, Suppl.: 99-117 (1977).

FAlkMer, S., Y. ÖStberg and S. VAN Noorden: Enteroinsular endocrine systems of cyclostomes: A clue to hormone evolution. In: (ed. by) S. R. BLoom: Gut hormones. Churchill Livingstone, Edinburgh-London-New York, 1978 (p. 57-63).

Falkmer, S., R. E. Carraway, M. El-Salhy, S. O. Emdin, L. Grimelius, J. F. Rehfeld, M. Reinecke and T. W. Schwartz: Phylogeny of the gastroenteropancreatic neuroendocrine system: A review. In: (ed. by) M. I. Grossman, M. A. B. Brazier and J. Lechago: Cellular basis of chemical messengers in the digestive system. Academic Press, London and New York, 1981 (p. 21-42).

Fritsch, H. A. R., S. Van Noorden and A. G. E. Pearse: Localisation of somatostatin- and gastrin-like immunoreactivity in the gastrointestinal tract of Ciona intestinalis L. Cell Tiss. Res. 186: 181-185 (1978).

- - Gastro-intestinal and neurohormonal peptides in the alimentary tract and cerebral complex of Ciona intestinalis (Ascidiaceae). Cell Tiss. Res. 223: 369-402 (1982).

Fujita, T. and S. Kobayashi : Proposal of a neurosecretory system in the pancreas. An electron microscope study in the dog. Arch. Histol. Jap. 42: 277-295 (1979).

Fujita, T., S. Kobayashi, R. Yui and T. Iwanaga: Evolution of neurons and paraneurons. In (ed. by) S. Ishii, T. Hirano and M. Wada: Hormones, adaptation and evolution. Japan Sci. Soc. Press, Tokyo, 1980 (p. 35-43).

Fujita, T., S. Kobayashi, S. Fuji, T. Iwanaga and Y. SERIZAW A : Langerhans islets as the neuro-paraneuronal control center of the exocrine pancreas. In (ed. by) M. I. Grossman, M. A. B. Brazier and J. Lechago: Cellular basis of chemical messengers in the digestive system. Academic Press, London and New York, 1981 (p. 231242).

HARDISTY, M. W. and B. I. BAKER: Endocrinology of lampreys. In: (ed. by) M. W. HARdisty and I. C. Pot. TER: The biology of lampreys, vol. 4B. Academic Press, London and New York, 1982 (p. 1-115).

LARSSON, L.-I., J. HOLST, R. HÅKANSON and F. SUNDLER: Distribution and properties of glucagon immunoreactivity in the digestive tract of various mammals: An immunohistochemical and immunochemical study. Histochemistry 44: 281-290 (1975).

NakAne, P. K. and G. B. Pierce Jr.: Enzyme-labeled antibodies: Preparation and application for the localization of antigens. J. Histochem. Cytochem. 14 : 929-931 (1966).

Ravazzola, M., A. Siperstein, A. J. Moody, F. Sundby, H. Jacobsen and L. ORCI: Glicentin immunoreactive cells: Their relationship to glucagon-producing cells. Endocrinology 105: 499-508 (1979).

REINECKE, M.: Immunohistochemical localization of polypeptide hormones in endocrine cells of the digestive tract of Branchiostoma lanceolatum. Cell Tiss. Res. 219: 445-456 (1981).

Reinecke, M., R. E. Carraway, S. Falkmer, G. E. Feurle and W. G. Forssmann: Occurrence of neurotensinimmunoreactive cells in the digestive tract of lower vertebrates and deuterostomian invertebrates. Cell Tiss. Res. 212: 173-183 (1980).

Sternberger, L. A.: Immunocytochemistry. PrenticeHall, Englewood Cliffs, 1974.

TAтемото, K.: Isolation and characterization of peptide YY (PYY), a candidate gut hormone that inhibits pancreatic exocrine secretion. Proc. Nat. Acad. Sci. USA 79: 2514-2518 (1982).

TitlbaCh, M. und H. F. KERN : Licht- und elektronenmikroskopische Untersuchungen am Inselorgan des Bachneunauges Lampetra planeri (Bloch). Z. Zellforsch. 97: 403-415 (1969).

Van Noorden, S. and A. G. E. Pearse: Immunoreactive polypeptide hormones in the pancreas and gut of the lamprey. Gen. Comp. Endocrinol. 23: 311-324 (1974).

: The localisation of immunoreactivity to insulin, glucagon and gastrin in the gut of Amphioxus (Branchiostoma) lanceolatus. In: (ed. by) T. A. I. Grillo, L. Leibson and A. Epple: The evolution of pancreatic islets. Pergamon Press, Oxford, 1976 (p. 163178).

Van Noorden, S., J. Greenberg and A. G. E. Pearse: Cytochemical and immunofluorescence investigations on polypeptide hormone localization in the pancreas and gut of the larval lamprey. Gen. Comp. Endocrinol. 19: 192-199 (1972).

Van Noorden, S., Y. Östberg and A. G. E. Pearse: Localization of somatostatin-like immunoreactivity in the pancreatic islets of the hagfish, Myxine glutinosa and the lamprey Lampetra fluviatilis. Cell Tiss. Res. 177: 281-285 (1977).

YUI, R. and T. FuJiTa: Immunocytochemical studies on the pancreatic islets of the ratfish Chimaera monstrosa. Arch. Histol. Jap. 49: 369-377 (1986).

Dr. Ryogo YUI

Department of Anatomy

Niigata University School of Medicine Asahimachi, Niigata

951 Japan

油井龍五

951 新潟市旭町通 1

新潟大学医学部

第三解剖学教室 